\title{
Ю Билеи
}

\section{$\mathbf{J}_{\text {UBILEES }}$}

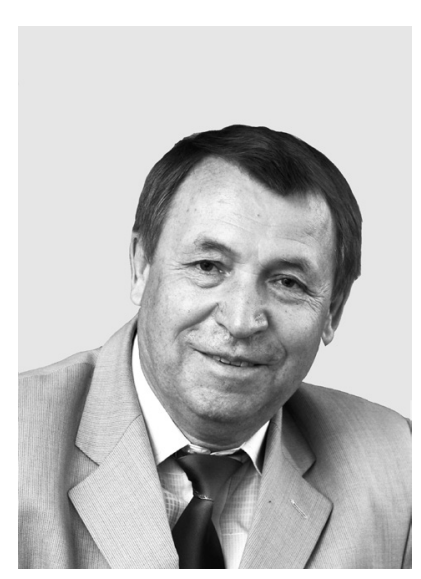

Известному белорусскому ученому, доктору социологических наук, профессору Виктору Васильевичу Кириенко 25 февраля исполнилось 75 лет. Жизненный путь Виктора Васильевича во многом схож с судьбами миллионов наших граждан, детство которых выпало на трудный и в то же время необыкновенно счастливый послевоенный период. Дети победителей, воспитывавшиеся, как правило, в больших крестьянских семьях, рано начинали трудиться и всего добивались самостоятельно. Они доверчивы, человеколюбивы и отзывчивы, чутки к чужому горю. А еще они надежны, не предают, живут с оптимизмом и верой.

Виктор Васильевич Кириенко родился в д. НовоНиколаевке Купинского района Новосибирской области (Россия). Он потомственный сибиряк, и это уже о многом говорит. Есть в его характере какаято основательность, неторопливость суждений, справедливость в оценках. В. В. Кириенко работал в местном совхозе, срочную службу проходил в Группе советских войск в Германии. Без отрыва от производства окончил вечернюю школу рабочей молодежи, в 1968 г. - отделение философии исто-

\section{Виктор Васильевич КИРИЕНКО}

\author{
Viktor Vasilievich \\ KIRIENKO
}

рического факультета БГУ. С 1969 г. живет в Гомеле. На предприятии «Гомсельмаш» он прошел путь от ученика слесаря до заместителя секретаря партийного комитета. Уже почти два десятилетия Виктор Васильевич работает в Гомельском государственном техническом университете имени П. О. Сухого (был секретарем парткома, старшим преподавателем, доцентом, проректором по учебной работе). В 1990 г. В. В. Кириенко первым в Беларуси защитил диссертацию на соискание ученой степени кандидата социологических наук. Виктор Васильевич создал в университете социологическую лабораторию, которая успешно работает до сих пор. Результатом научных изысканий В. В. Кириенко стала защита в 2007 г. докторской диссертации на тему «Менталитет современных белорусов (социологический анализ)» в Институте социологии НАН Беларуси (научный консультант - академик НАН Беларуси Е. М. Бабосов).

По инициативе Виктора Васильевича на базе Гомельского государственного технического университета имени П. О. Сухого ежегодно проводится международная конференция «Менталитет славян и интеграционные процессы: история, современ- 
ность, перспективы». За большой личный вклад в изучение и популяризацию славянской культуры В. В. Кириенко награжден медалью «100 лет славянскому движению на землях Беларуси (1909-2009)» и юбилейной медалью Франтишека Палацкого (2008). Профессор В. В. Кириенко, для которого быть учителем - настоящее призвание, был награжден нагрудным знаком «Отличник образования».
Мы искренне поздравляем Вас, дорогой Виктор Васильевич, со славным юбилеем! Желаем, чтобы и дальше по жизни Вы шли так же уверенно и неторопливо, обстоятельно и примерно выполняя свой долг на Земле, неся людям добро, спокойствие и уверенность в завтрашнем дне!

А. Н. Данилов ${ }^{1}$

\footnotetext{
${ }^{1}$ Александр Николаевич Данилов - член-корреспондент НАН Беларуси, доктор социологических наук, профессор; заведующий кафедрой социологии факультета философии и социальных наук Белорусского государственного университета.

Alexander N. Danilov, corresponding member of the National Academy of Sciences of Belarus, doctor of science (sociology), full professor; head of the department of sociology, faculty of philosophy and social sciences, Belarusian State University.

E-mail:a.danilov@tut.by
} 